\title{
NEW CAPABILITIES OF THE OLDEST ENTERPRISE ON PRODUCTION OF WELDING FLUXES
}

\author{
A.V. ZALEVSKY ${ }^{1}$, V.I. GALINICH ${ }^{1}$, I.A. GONCHAROV ${ }^{1}$, N.Ya. OSIPOV ${ }^{2}$, \\ V.I. NETYAGA ${ }^{2}$ and O.P. KIRICHENKO ${ }^{2}$ \\ ${ }^{1}$ E.O. Paton Electric Welding Institute, NASU \\ 11 Bozhenko Str., 03680, Kiev, Ukraine. E-mail: office@paton.kiev.ua \\ ${ }^{2}$ Company «Zaporozhstekloflyus» \\ 2 Diagonalnaya Str., 69035, Zaporozhie, Ukraine. E-mail:contact@steklo.zp.ua
}

\begin{abstract}
At Company «Zaporozhstekloflyus» the technology of two-stage melting of flux (duplex-process) was mastered, where firstly the charge is melted in separate melting unit, and then the melt is finally melted in another unit. This allowed decreasing the content of harmful impurities in melt: oxides of iron and sulphur by $2-3$ times, phosphorus - by 4-6 times, and, thus, improving the flux quality. In addition, raw base for production of fused fluxes was widened that is extremely important under conditions of deterioration of raw material quality. Due to the double refining of melt of fluxes the duplex-process solved in principle the problem of utilization of slag crust, formed in submerged-arc welding. Production of fused semi-products designed for application in charge of welding consumables (covered electrodes, flux-cored wires and agglomerated fluxes) was mastered. 5 Ref., 1 Table, 1 Figure.
\end{abstract}

Key words: welding fluxes, duplex-process, melt refining, slag base, special fused products, sodium silicate

Submerged-arc welding is the leading technological process in manufacture of large-size welded metal structures. Among four components of this process, such as welding equipment, base metal, welding wire and flux, a high quality of the latter and its welding-technological capabilities provide a user with required technical and economical characteristics of welding, and remain a decisive factor for a manufacturer of fluxes in sale of the own products.

However, the traditional technologies of manufacture of welding fused fluxes, i.e. melting in open gas or electric arc furnaces can already scarcely deal with this problem. The reasons are not only in deterioration of quality of traditional raw materials and growth of requirements to the quality of welded metal structures, but also in the technologies themselves, as each transition in flux melting from one grade to another or change in quality of charge consumables determine the efficiency of flux melting furnaces, influences the life of lining, predetermine the volume of consumption of power carriers, and result, as a rule, in additional production costs.

In the last years the requirements to restriction of content of harmful impurities in steels of critical welded structures were rapidly increased [1, $2]$. To provide the required characteristics of quality of welded joints, it is necessary to restrict the content of these impurities in fluxes. Ther- modynamic analysis of pyrometallurgical processes, running in flux melting furnaces, showed complications of simultaneous decrease in sulphur and phosphorus in the melt [3].

Appearance of two-stage flux melting (duplex-process) [4], at which the charge is melted at the separate melting unit and then at the second one its refining is performed, allows not only decreasing the content of oxides of iron, sulphur and phosphorus in the melt and thus improving the quality of flux, but also extending the source of raw materials for production of fused fluxes, which is extremely important under the conditions of deterioration of quality of raw materials. Besides, due to double refining of melt of fluxes the duplex process almost solved the problem of utilization of slag crust, formed during submerged-arc welding, which thus allowed decreasing the negative effect on the environment. Thus, since the moment of implementation of this technology (2000) within the frames of innovation project of the PWI Technopark, at the «Zaporozhstekloflyus» $32,279 \mathrm{t}$ of slag of production of silicomanganese and $31,328 \mathrm{t}$ of slag crust of flux AN-60 was utilized as well as agglomerated fluxes used in production of large-diameter pipes at Hartsyzsk Pipe Plant.

Separation of flux melting into two stages provides certain economic advantages: the main consumptions of heat are spent to decomposition and melting of charge consumables at relatively low temperatures, therefore for this purpose it is eco- 
nomically rational to use cheaper power carriers (coal dust, coke gas) instead of electric power. The latter is used only to increase the temperature of a melt for its deoxidation, removal of phosphorus and iron oxides and formation of the required pumice-like grain structure during the following granulation.

From the metallurgical point of view the principal change in the processes of melt refining occurs, i.e. the process of desulphuration occurs separately from the dephosphorization process. Such double refining allows conducting more profound purification of melt from harmful impurities: sulphur and iron oxides by $2-3$ times and phosphorus by $4-6$ times. The results of investigations of refining process of melt of flux AN-348A applying the traditional technology (in open gas furnace) and duplex-process are given in the Figure.

Such wide technological capabilities of duplex-process allowed extending the nomenclature of products of «Zaporozhstekloflyus», as well as starting the production of pumice-like and agglomerated fluxes and also mastering the production of consumables as raw materials for manufacture of the latter. Thus, the production of agglomerated fluxes at the mentioned enterprise is performed almost on the own source of raw materials. For example, for manufacture of flux ANKS-28 a slag base of charge was melted, which contained traditional raw materials: slag of silicomanganese, fluorspar, dolomite, crust of used flux, etc. On the base of this flux the technology of surfacing of roller tracks of MP-350 mixers was developed, which at the necessary quality of tracks (absence of cracks, hardness of deposited layer in the limits of $H R C 36-38$ ) does not require heat treatment of deposited metal, increases efficiency of deposition twice, decreases laborintensiveness of deposition and consumption of electric power by $30-40 \%$.

At the present time at «Zaporozhstekloflyus» the industrial production of new products, such as special fused products designed for use in charge at production of agglomerated fluxes, flux-cored wires and other welding consumables was mastered:
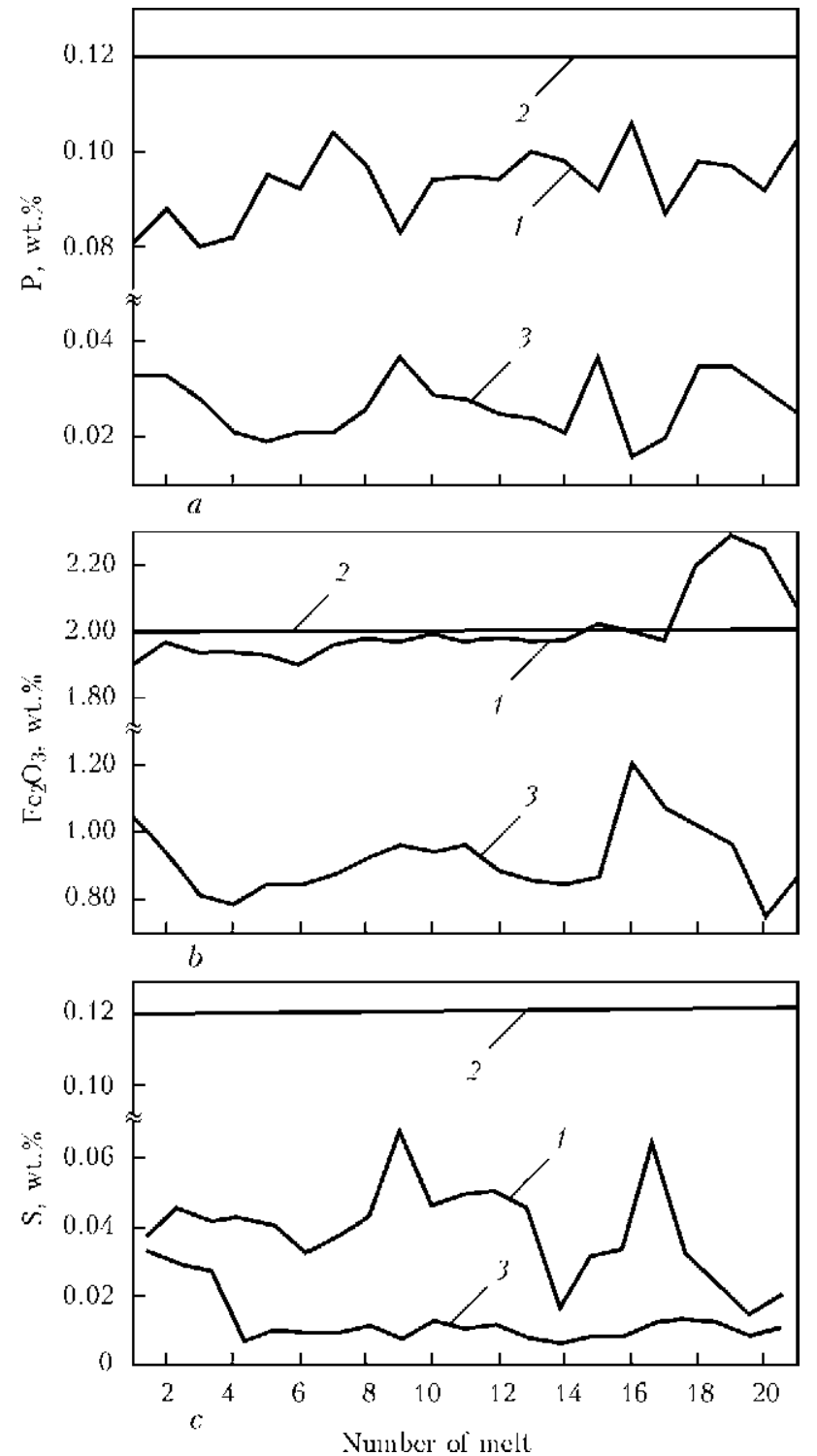

Statistic data on change or content of phosphorus $(a)$, iron oxides $(b)$ and sulphur $(c)$ in melt during melting of flux AN-348A using traditional technology in open gas furnace (1) and duplex-process (3); 2 - norm acc. to GOST 9087

- grade MS represents a refined manganese slag (basicity index according to Bonishevsky is less than 1.0);

- CS - the slag of neutral type with refined properties (basicity index according to Bonishevsky is 1.1);

- AR - the slag of aluminate-rutile type with good welding and technological properties (basicity index according to Bonishevsky is 0.6).

Chemical composition of fused products, wt.\% (maximum values of sulphur $-0.03 \%$, carbon $-0.1 \%$ )

\begin{tabular}{|c|c|c|c|c|c|c|c|c|c|}
\hline \hline Type & $\mathrm{MnO}, \%$ & $\mathrm{SiO}_{2}, \%$ & $\mathrm{CaO}, \%$ & $\mathrm{Al}_{2} \mathrm{O}_{3}, \%$ & $\mathrm{Fe}_{2} \mathrm{O}_{3}, \%$ & $\mathrm{MgO}, \%$ & $\mathrm{CaF}_{2}, \%$ & $\mathrm{TiO}_{2}, \%$ & $\mathrm{P}, \%$ \\
\hline $\mathrm{MS}$ & $34-41$ & $34-41$ & $7-12$ & $2-8$ & $1.5(\max )$ & $0.5-3.0$ & $3-7$ & $1(\max )$ & $0.06(\max )$ \\
\hline $\mathrm{CS}$ & $6-8$ & $34-38$ & $19-23$ & $12-15$ & $1.5(\max )$ & $11-15$ & $6-10$ & $4-7$ & $0.07(\max )$ \\
\hline $\mathrm{AR}$ & $8-12$ & $16-18$ & $6-10$ & $30-34$ & $2.2(\max )$ & $7(\max )$ & $4-8$ & $16-19$ & $0.06(\max )$ \\
\hline
\end{tabular}


The compositions of fused products are given in the Table.

The enterprise has a potential to manufacture fused slag base for agglomerated fluxes of aluminate-basic type, for example, similar to fluxes UV-309 P or OP-132. The Plant, being the largest manufacturer of sodium silicate (glass block) in CIS countries and Europe, is establishing the modern production of liquid glass for the needs of different branches of domestic economy: production of welding consumables, detergents, construction.

Duplex-process has also a positive influence on welding and technological properties of traditional grades of fluxes. Thus, the standard flux of the grade AN-348A with the bulk density of $0.9-1.1 \mathrm{~g} / \mathrm{cm}^{3}$ (AN-348AP grade of flux), manufactured using method of duplex refining, was tested at the Company «Word Building Systems Ukraine» in welding [5] of:

- butt welds in manufacture of girths of main girders of steel 09G2SD of $32 \mathrm{~mm}$ thickness with $\mathrm{X}$-edge preparation using wire of the grade $\mathrm{Sv}$ 08GA of $4 \mathrm{~mm}$ diameter for the bridge at the speedway Kiev-Odessa;

- in welding of girth welds of double T-girders of thin-sheet steel 09G2S using wire Sv-08G2S of $1.2 \mathrm{~mm}$ diameter;

- in manufacture of girders of steel St3 of $12 \mathrm{~mm}$ thickness at the Lincoln automatic production line «Conrak» at simultaneous welding, using wires Sv-08GA of $1.6 \mathrm{~mm}$ diameter, of two butts in flat position using two arcs into the one pool for each butt. Earlier for this purpose the ceramic flux Lincoln 780 was applied. In all variants of welding the pores, cracks, undercuts and roughness at the surface of welds were absent. Here pumice-like flux AN-348AP provided a selfremoval of slag crust at the second and next passes, uniform formation of weld metal with smooth transition to the base metal and fine-rippled surface of silver color, monotonous along the whole length of a butt, which rendered the best marketable state of a product as compared to the earlier applied glass-like fluxes AN-348A and AN-348AM. Especially the tests of modernized flux AN-348AP of fine granulation at automatic production line «Conrak» should be noted, where it surpassed the agglomerated flux Lincoln 780 by all the characteristics. The flux AN-348AP according to TU U 05416923.049-99 is successfully applied at this enterprise since 2004 .

Alongside with the famous grades of fluxes AN-348A, AN-60, AN-47, OSTs-45, manufactured according to GOST 9087, TU U 05416923.049-99 and Russian standard GOSTR 52222 , and used in welding of low-alloyed and carbon steels, «Zaporozhstekloflyus» produces also fluxes of grades AN-20S, AN-20P, AN-20SP, AN-26 for welding and surfacing of stainless steels.

To perform speed welding of large-diameter pipes of low-alloyed steels of conventional and increased strength, as well as bridge structures, sheet panels of tanks, the production of pumicelike flux of the grade AN-47DP was developed and mastered. Its industrial tests showed that it is the only flux, which provides normal formation of inner weld in welding of spirally-welded pipes.

At the present time «Zaporozhstekloflyus» performs modernization of flux-melting workshop for production of high-quality fused fluxes with a wide range of consumer properties following the new technology.

The industrial line on production of agglomerated fluxes of productivity of up to $5000 \mathrm{t}$ per year was created, which provides organizing the production of domestic agglomerated fluxes in Ukraine. Application of agglomerated fluxes of fused products in industry instead of expensive imported charge components will provide a high quality of fluxes and their compatibility not only at the Ukrainian but also at the world market.

1. Morozov, Yu.D., Matrosov, M.Yu., Nastich, S.Yu. et al. (2008) High strength pipe steels of new generation with ferritic-bainitic structure. Metallurg, 8, 39-42.

2. Pogozhev, A.V., Tskitishvili, E.O., Matrosov, Yu.I. et al. (2013) Experience of application of accelerated cooling in manufacturing of steel plate 70 for pipes of gas pipeline «Middle Asia-China». Ibid., 3, 66-70.

3. Zhdanov, L.A., Duchenko, A.N., Goncharov, I.A. et al. (2012) Thermodynamic analysis of slag melts in manufacture of fused welding fluxes. The Paton Welding J., 11, 23-27.

4. Mednikov, Yu.A., Plyasunov, V.A., Zhuchaev, V.A. et al. (1997) Mastering of new technology of welding flux melting. Stal, 9, 42-43.

5. Duda, N.I., Galinich, V.I., Zalevsky, A.V. (2004) Experience of application of fused pumice-like flux of AN-34AP grade. Svarshchik, 4, 24-25.

Received 24.04.2014 